\title{
FEATURES OF REVASCULARIZATION OF THE LOWER EXTREMITY IN PATIENTS WITH DIABETIC FOOT
}

\author{
D. Shapovalov, Y. Hupalo, V. Shaprynskyi, A. Shamray-Sas, A. Kutsin, V. Gurianov \\ State Institution of Science «Research and Practical Center of Preventive and Clinical Medicine» State Administrative Department, Kyiv, Ukraine
}

\section{Summary}

Background. Peripheral arterial diseases in patients with diabetic foot (PAD/DF) have significant differences in pathogenesis, manifestations and course compared with peripheral arterial diseases (PAD). These differences cause creating classifications to access severity PAD/DF and PAD separately. But approaches to revascularizations in PAD/DF and PAD remain the same. The choice of revascularization method taking into account the features can significantly improve its results.

Aim: to determine specific features of peripheral arterial diseases in patients with diabetic foot that influence the choice of revascularization method.

Material and methods. We analyzed results of 98 revascularizations of 77 lower extremities in 74 patients in the period from 2014 to 2019. Angioplasties were performed 72,3\%, open operations $21,4 \%$, hybrid procedures $6,1 \%$.

Results. Amputation-free survival during the year was $84,6 \%$. Healing of trophic disorders during the year was $70,5 \%$.

Conclusions. At the diagnostic stage, patients with PAD and PAD / DF should be separated for creating the optimal treatment plan and the choice of revascularization technique. Different approaches to the PAD/DF patients can improve the results of revascularizations.

Key words: peripheral arterial diseases, diabetic foot, angiosome-targeted revascularization, angioplasty

\section{INTRODUCTION}

PAD of the lower extremities are common age-related pathology which significantly impair the quality of life and lead to disability of people over 50 years. In the trial PARTNERS (PAD, Awareness, Risk and Treatment: New Resources for Survival) were examined 6979 people over 50 years in 320 clinics (USA). PAD were found in $29 \%$ (1865 patients) [1].

Diabetics are 2.7 times more prone to peripheral artery disease than people of the same age without diabetes [2].

The probability of large amputation in PAD/DF is six times higher than in non-diabetics [3].

\footnotetext{
Amputation-free survival as an important factor of the lifetime.

The results of a multicenter randomized BASIL study were published in 2010. The results of revascularization in 452 patients with severe ischemia of the lower extremity
}

were analyzed, the monitoring period was 3 years. Open interventions were performed 228, endovascular interventions -224 .

$50-90 \%$ of patients survived for 2 years. The large discrepancy is due to risk factors: old age, overweight, diabetes, renal failure, arteries below the knee, and so on.

172 patients (38\%) escaped high amputation By the end of the follow-up period - 3 years - 202 (45\%) of which survived. That is, $84.4 \%$ of the survivors were patients whose limb was saved. The authors of the study emphasize the need for a differentiated approach to the choice of revascularization techniques taking into account risk factors [4].

Mortality after major amputation is significantly higher for patients with diabetes compared to non-diabetes patients. At the first week mortality rate was $30 \%$ for diabetes patients versus $8 \%$ non-diabetes patients, at 1 year $80 \%$ versus $57 \%$ [5]. 


\section{PATHOMORPHOLOGICAL FEATURES PAD/DF}

Typical localisation of artery lesions in PAD/DF:

According to the literature the arteries lesions in diabetes are localized in below-the-knee arteries in 74\% [6]

According to our data, hemodynamically significant lesions in below-the-knee arteries were found in $83.33 \%$ of cases.

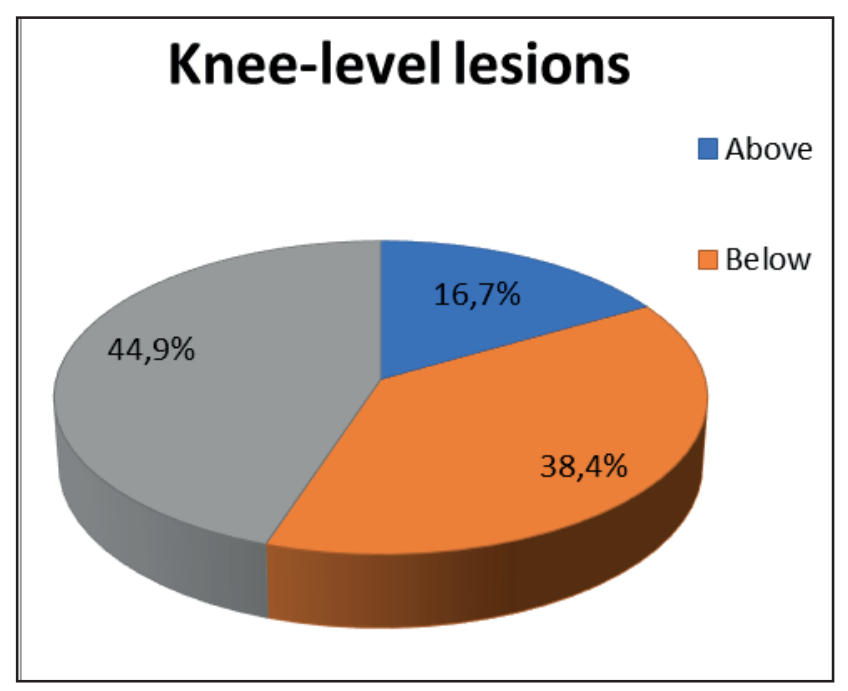

Microangiopathy: DM is characterized by pathological changes in the arterioles and capillaries thickening, which is another factor that impairs the trophism of the tissue of the foot. Microangiopathy is an additional factor that enlarges tissue ischemia of the foot and speeds up the development of necrotic changes.

Neuropathy and PAD/DF: One of the leading factors in the development of PAD /DF, in addition to those mentioned above, is diabetic neuropathy. The common consequences of neuropathy are the absence of pain, reduced local tissue response, impaired human behavioral response to tissue damages.

Neuropathy affects pathological changes in the arterial wall. The damage to the autonomic innervation of the arterial wall causes dysfunction of myocytes, their transformation into connective tissue cells, replacement of myocytes with connective tissue, which leads to the formation of atherosclerotic plaques [7].

Mediacalcinosis is typical for diabetic lesions of the arterial wall and is also a consequence of neuropathy. Normally, vascular smooth muscle cells under the influence of sympathetic innervation produce inhibitors of calcium uptake and retention. In diabetic neuropathy, sympathetic nerve damage inhibits the synthesis of calcification inhibitors and promotes calcium deposition in the middle layer of the arterial wall [8].

Dependence of diabetic neuropathy on PAD. In a cohort study by E. Faglia et al. [9]. Angiography was performed on
567 diabetics with signs of critical foot ischemia (trophic disorders, pain at rest) to diagnose arterial lesions. According to her results, out of 567 , only 3 patients did not have hemodynamically significant (>50\% of the lumen) stenoses of the arteries of the lower extremities.

Infection: A pathological state caused by invasion and multiplication of microorganisms in host tissues accompanied by tissue destruction and/or a host inflammatory response. Typical progression of the diabetic foot infection is in the IDSA/IWGDF [10].

Studies of the amputated limb arteries have shown infection of atherosclerotic plaques much proximal to the area of trophic lesions of the foot and leg. The authors suggest that the accession of bacterial infection of the walls of arteries or atherosclerotic plaques may be a synergistic factor that worsens the course of the disease and leads to amputation of the limb faster [11].

\section{PAD AND PAD/DF CLASSIFICATIONS}

The correct choice of classification allows to adequately assess the clinical case and choose the right treatment tactics

Confusion due to the use of several classification systems prevents the development of optimal treatment algorithms for patients with chronic lower extremity ischemia [12]

The main clinical signs of PAD are given in the most common classifications Fontain and Rutherford.

In cases PAD without diabetes the main symptom is intermitten claudication. Foot trophic disorders are considered signs of the last stages before the threat of the loss of the limb.

Fontain classification.

I ст. Asymptomatic, incomplete blood vessel obstruction. II ст. Mild claudication pain in limb.

IIa. Claudication at a distance $<200 \mathrm{~m}$

IIб. Claudication at a distance $<200 \mathrm{~m}$

III ст. Rest pain, mostly in the feet

IV ст. Necrosis and/or gangrene of the limb.

The classification is based on the patient's subjective assessment of the pain syndrome, the objective signs - necrotic changes - are assessed only at the last stage. Rutherford's classification is similar in principle, but uses the ankle-shoulder index as an objective criterion.

\section{PAD/DF: COMPARATIVE FEATURES}

When combining PAD and diabetes mellitus, the development and manifestations of ischemia are significantly influenced by the above pathogenetic factors.

Infection, ulceration or destruction of tissues of the foot associated with neuropathy and/or peripheral artery disease in the lower extremity of a person with (a history of) diabetes mellitus [10]. 
In PAD/DF, unlike PAD, trophic changes of the lower leg and foot in the form of ulcers and focal necrosis may be only the beginning of the disease, ischemia is not always a mandatory component.

Correct assessment of the severity of tissue damage, the influence of certain pathogenetic factors required detailed classifications.
Modern classifications recommended by the International Working Group of Diabetic Foot [10] - WIFi, IWGDF/IDSA and SYNBAD.

SINBAD classification is recommended for severity assessment trophic disorders.

SINBAD classification.

\begin{tabular}{|l|l|c|}
\hline \multicolumn{1}{|c|}{ Category } & \multicolumn{1}{c|}{ Definition } & Score \\
\hline \multirow{2}{*}{ Site } & Forefoot & 0 \\
\cline { 2 - 3 } & Middlefoot or hitefoot & 1 \\
\hline \multirow{2}{*}{ Ischemia } & Pedal blood flow intact: at least one palpable pulse & 0 \\
\cline { 2 - 3 } & Clinical evidence of reduced pedal flow & 1 \\
\hline \multirow{2}{*}{ Neuropathia } & Protective sensation intact & 0 \\
\cline { 2 - 4 } & Protective sensation lost & 1 \\
\hline Bacterial infection & None & 0 \\
\hline & Present & 1 \\
\hline Area & Ulcer $<1$ sm & 0 \\
\hline & Ulcer $>1$ sm & 1 \\
\hline Depth & Ulcer confined to skin and subcutaneous tissue & 0 \\
\hline & Ulcer reaching muscle, tendon or deeper & 1 \\
\hline Total & & 6 \\
\hline
\end{tabular}

So a small uninfected trophic ulcer gains $0-1$ points in contrast to the Fontain classification, according to which trophic changes correspond to stage IV, the most severe. To assess the severity of the infec- tious process IWGDF/IDSA System is recommended. WIfI system classification is recommended for a comprehensive assessment of the severity of the foot and treatment prospects

\section{WIfl system: Wound, Ischemia, Foot infection}

\begin{tabular}{|c|l|l|}
\hline $\begin{array}{c}\text { Wound } \\
\text { grade }\end{array}$ & \multicolumn{1}{|c|}{ Diabetic foot ulcer (DFU) } & \multicolumn{1}{c|}{ Gangrene } \\
\hline \multirow{2}{*}{0} & \multicolumn{1}{|c|}{ No ulcer } & \multicolumn{1}{c|}{ No gangrene } \\
\cline { 2 - 3 } & Clinical description: minor tissue loss. Salvageable with simple digital amputation (1 or 2 digits) or skin coverage. \\
\hline \multirow{3}{*}{1} & $\begin{array}{l}\text { Small, shallow ulcer(s) on distal leg or foot; no } \\
\text { exposed bone, unless limited to distal phalanx }\end{array}$ & No gangrene \\
\cline { 2 - 3 } & Clinical description: minor tissue loss. Salvageable with simple digital amputation (1 or 2 digits) or skin coverage. \\
\hline \multirow{3}{*}{2} & $\begin{array}{l}\text { Deeper ulcer with exposed bone, joint or tendon; generally not } \\
\text { involving the heel; shallow heel ulcer, without calcaneal involvement }\end{array}$ & Gangrenous changes limited to digits \\
\cline { 2 - 3 } & $\begin{array}{l}\text { Clinical description: major tissue loss salvageable with multiple ( } \geq 3) \text { digital amputations or } \\
\text { standard transmetatarsal amputation (TMA) } \pm \text { skin coverage. }\end{array}$ \\
\hline \multirow{2}{*}{3} & $\begin{array}{l}\text { Extensive, deep ulcer involving forefoot and/or midfoot; } \\
\text { deep, full thickness heel ulcer } \pm \text { calcaneal involvement }\end{array}$ & $\begin{array}{l}\text { Extensive gangrene involving forefoot and } \\
\text { /or midfoot; full thickness heel necrosis } 6 \\
\text { calcaneal involvement }\end{array}$ \\
\cline { 2 - 3 } & $\begin{array}{l}\text { Clinical description: extensive tissue loss salvageable only with a complex foot reconstruction or non-traditional } \\
\text { TMA (Chopart or Lisfranc); flap coverage or complex wound management needed for large soft tissue defect }\end{array}$ \\
\hline
\end{tabular}




\begin{tabular}{|c|c|c|c|}
\hline $\begin{array}{c}\text { Ischemia } \\
\text { Grade }\end{array}$ & Ankle-Brachial Index & $\begin{array}{c}\text { Ankle systolic pressure } \\
\text { (mmHg) }\end{array}$ & $\geq 60$ \\
\hline 0 & $\geq 0.80$ & $>100$ & $40-59$ \\
\hline 1 & $0.6-0.79$ & $70-100$ & $30-39$ \\
\hline 2 & $0.4-0.59$ & $50-70$ & $<30$ \\
\hline 3 & $\leq 0.39$ & $<50$ & \\
\hline
\end{tabular}

\begin{tabular}{|c|c|}
\hline $\begin{array}{c}\text { Foot infection } \\
\text { Grade }\end{array}$ & Clinical manifestation \\
\hline 0 & $\begin{array}{l}\text { No symptoms or signs of infection } \\
\text { Infection present, as defined by the presence of at least } 2 \text { of the following items: } \\
\text { - Local swelling or induration } \\
\text { - Erythema }>0.5 \text { to } \leq 2 \mathrm{~cm} \text { around the ulcer } \\
\text { - Local tenderness or pain } \\
\text { - Local warmth } \\
\text { - Purulent discharge (thick, opaque to white, or sanguineous secretion) }\end{array}$ \\
\hline 1 & $\begin{array}{l}\text { Local infection involving only the skin and the subcutaneous tissue (without involvement of } \\
\text { deeper tissues and without systemic signs as described below). } \\
\text { Exclude other causes of an inflammatory response of the skin (e.g., trauma, gout, acute Charcot neuro- } \\
\text { osteoarthropathy, fracture, thrombosis, venous stasis) }\end{array}$ \\
\hline 2 & $\begin{array}{l}\text { Local infection (as described above) with erythema }>2 \mathrm{~cm} \text {, or involving structures deeper than skin and } \\
\text { subcutaneous tissues (e.g., abscess, osteomyelitis, septic arthritis, fasciitis), and } \\
\text { No systemic inflammatory response signs (as described below) }\end{array}$ \\
\hline 3 & $\begin{array}{l}\text { Local infection (as described above) with the signs of SIRS, as manifested by two or more of } \\
\text { the following: } \\
\text { - Temperature }>38^{\circ} \mathrm{C} \text { or }<36^{\circ} \mathrm{C} \\
\text { - Heart rate }>90 \text { beats } / \text { min } \\
\text { - Respiratory rate }>20 \text { breaths } / \mathrm{min} \text { or } \mathrm{PaCO} 2<32 \mathrm{~mm} \mathrm{Hg} \\
\text { - White blood cell count }>12,000 \text { or }<4000 \mathrm{cu} / \mathrm{mm} \text { or } 10 \% \text { immature (band) forms }\end{array}$ \\
\hline
\end{tabular}

The leading pathogenetic factor in PAD is ischemia and surgical revascularization is the main way to the limb salvage.

In PAD/DF the foot revascularization is only a component of comprehensive treatment in contrast to PAD. Adequate and timely debridement, control of infection, unloading of the affected parts of the foot, preservation of active support function of the foot are necessary to save the limb.

\section{CLINICAL PURPOSE OF REVASCULARIZATION IN THE PAD/DF}

The main purpose of revascularization is the Improving of Quality of Life (IQL). We defined IQL as sufficient distance of active walking, reduction of pain and healing of trophic disorders.

Limb salvage we defined not only as amputation-free survival, but also the saving of the supporting function of the foot without additional mobility devices (wheelchairs, crutches). This is the similar to the definition of Tefera et al. 2005 [13].

\section{Improving of quality of life

\begin{tabular}{|c|}
\hline \hline 2. Limb salvage \\
\hline 3. Healing of trophic disorders \\
\hline
\end{tabular}

\section{TECHNICAL PURPOSE OF REVASCULARIZATION IN THE PAD/DF}

In PAD and PAD/DF the main task is to increase blood flow to the limb.

In 2007 within the framework of the international consensus TASK-II, a classification of lesions of the arteries of the lower extremities was developed with recommendations for the use of surgical methods of revascularization [14].

In patients with $\mathrm{PAD} / \mathrm{DF}$ is important to direct blood flow to the one of foot arteries, preferably the artery that supplies the lesion area - wound related revascularization [10].

Wound-related revascularization is possible due to the angiosome theory [15].

Angiosome-directed revascularization is directing of the blood flow to the affected area according to anatomical pattern of blood supply to the skin and subcutaneous tissue.

Adherence to the angiosomal concept can significantly increase the likelihood of limb salvage and healing of trophic lesions in patients with PAD / DF [16,17,18].

Development of endovascular techniques allows to restore blood flow in the small arteries of the foot [19]. This can be achieved through the use of X-ray endovascular techniques. Therefore in patients with PAD/DF angioplasty is the first strategy in the world [20]. 
OUR RESULTS OF REVASCULARIZATIONS IN PAD/DF.

\section{Materials and methods}

We analyzed results of 98 revascularizations of 77 lower extremities in 74 patients in the period from 2014 to $2019 \mathrm{pp}$.

Males - 47 (59,5\%), females - $30(40,5 \%)$. Average age of patients $-68,4 \mathrm{p}$. All patients had trophic disorders of the foot (100\%), in three of them - on the two lower extremities $(4,1 \%)$. The most common type of lesions was focal necrosis or gangrene of the toes $-45(58,4 \%)$. The second typical lesion was postoperative wounds that do not heal $-11(14,3 \%)$.

\section{Planning of revascularization.}

Indications for revascularization were considered to be trophic disorders of the lower extremity and the absence of pulsation of the arteries of the foot.

Details of occlusal-stenotic lesions and the possibility of using one of the methods of revascularization were determined using ultrasound performed on Mindray 5 and Sonoace R3. If the obtained data were insufficient for the choice of revascularization method, angiography was planned. Angiography was performed on a Philips Alura F920.

Based on the obtained data, the optimal method of revascularization was chosen - X-ray endovascular angioplasty, open or hybrid. The feasibility of the chosen intervention in each patient was assessed according to the «risk / benefit» ratio [10].

First of all, we considered the possibility of angioplasty - «Angioplasty-first strategy». Other techniques were chosen with the predicted ineffectiveness of endovascular intervention.

Open vascular surgery was planned in case of predicted ineffectiveness of angioplasty or inefficiency of previous endovascular intervention.

Hybrid interventions were chosen mainly for stenoses and occlusions of the tibial and foot arteries complicated by proximal or distal thrombosis.

Angioplasty, open and hybrid surgical techniques were used to restore blood supply.

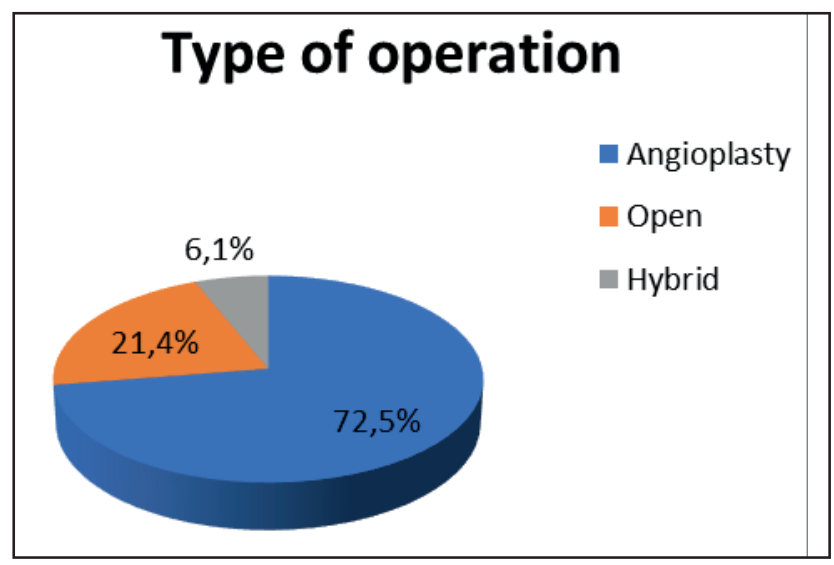

\section{Statistical analisys}

The analysis of the research results was performed in the package EZR v.1.50 (R statistical software version 4.0, R Foundation for Statistical Computing, Vienna, Austria) [21].

\section{Results}

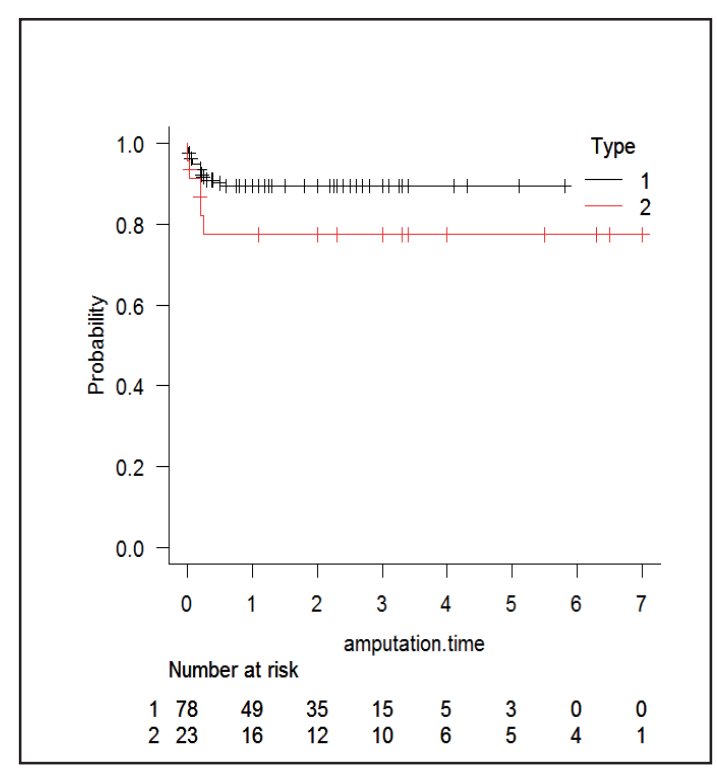

Amputation-free survival during the year was $84,6 \%$.

There was no statistically significant difference in the type of operation (p.value $=0.141)$.

Type 1 - angioplasty and hybrid revascularization.

Type 2 - open revascularization. 


\section{Healing of the trophic disorders was $70,5 \%$ during the year.}

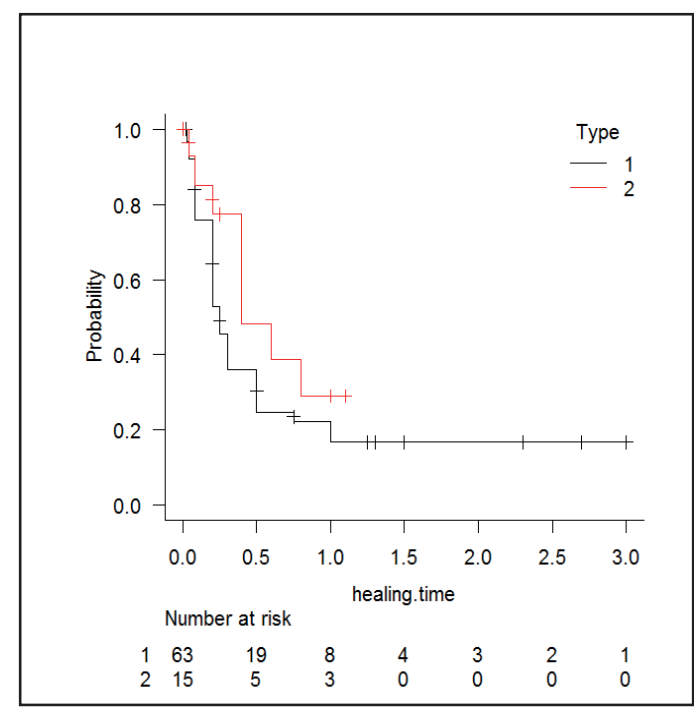

\section{Wound-related revascularization}

According to our data, adherence to the angiosomal theory increases the probability of preservation of the limb (p.value $=0,939$ ), but has almost no effect on the timing of healing ( $\mathrm{p}$.value $=0,0118$ ). The timing of healing in general is very variable due to many factors that affect them.

\section{Discussion}

Revascularization in PAD/DF patients has different consequences than in PAD. Restoration of blood flow in PAD / DF causes the activation of inflammation aimed at the rejection of necrotized infected tissues - reperfusion syndrome. The result may be an outbreak of purulent-septic processes with the spread of the fascial spaces of the foot, which is typical for diabetes. This requires active control of infection, debridement.

Elimination of nerve ischemia can lead to increased pain and reduces the running activity of the patient. At the same time, active dosed walking is a necessary component of maintaining the blood supply to the foot in the postoperative period. Therefore, the treatment of neuropathy and analgesia plays an important role.

The need for debridement, off-loading with simultaneous active maintenance of foot support func- tion, VAC-therapy, control of infection and increased local inflammation due to reperfusion syndrome requires a proper multidisciplinary approach to treatment after revascularization.

\section{Conclusions:}

The same treatment of PAD and PAD/DF patients leads to a large number of major amputations due to incorrect assessment of the consequences of revascularization.

At the diagnostic stage, patients with PAD and PAD / DF should be separated for creating the optimal treatment tactics.

The revascularization technique should be chosen taking into account the characteristics of the PAD/DF.

Different approach to the PAD/DF patients can improve the results of revascularizations

\section{Next research prospects:}

Study of the revascularization results based on the differences between PAD and PD / DM can improve the treatment of these pathologies or prove the effectiveness of the overall approach.

\section{ЛITEPATУРA}

1. Hirsch A. T., Hiatt W. R. PARTNERS: PAD, Awareness, Risk and Treatment: New Resources for Survival. Vascular Medicine. 2001. 6 (3). P. 9-12. URL: https://pubmed.ncbi. nlm.nih.gov/11789964/ doi: 10.1177/1358836X0100600i103
2. Selvin E., Erlinger T. P. Prevalence of and risk factors for peripheral arterial disease in the United States: results from the National Health and Nutrition Examination Survey. Circulation. 2004. 110 (6). P. 738-743. URL: 
https://pubmed.ncbi.nlm.nih.gov/15262830/ DOI: doi: 10.1161/01.CIR.0000137913.26087.F0.

3. Ahmad N., Thomas G. N., Paramjit G., Torella F. The prevalence of major lower limb amputation in the diabetic and non-diabetic population of England 2003-2013. Diabetes \& Vascular Disease Research. 2016. Vol. 13, № 5. P. 348-353. URL: https:// pubmed.ncbi.nlm.nih.gov/27334482/ DOI: doi: 10.1177/1479164116651390

4. BASIL Trial Participants: Bypass versus Angioplasty in Severe Ischaemia of the Leg (BASIL) trial: A survival prediction model to facilitate clinical decision making / Bradbury A. W., et al. Journal of Vasularc Surgery. 2010. № 51. P. 52-68. URL: https://pubmed.ncbi.nlm.nih. gov/15262830/. DOI: doi: 10.1016/j.jvs.2010.01.077

5. Sjödin L., Enocson A., Rotzius P. Increased mortality among patients with diabetes following first-ever transfemoral amputation. Diabetes Research and Clinical Practice. 2018. № 143. P. 225-231. URL: https://pubmed.ncbi.nlm.nih.gov/30009936/. DOI: doi: $10.1016 / \mathrm{j}$.

6. Graziani L. et al. Vascular Involvement in Diabetic Subjects with Ischemic Foot Ulcer: A New Morphologic Categorization of Disease Severity. European Journal of Vasular and Endovascular Surgery. 2007. № 33. P. 453-460. URL: http://www.sciencedirect.com, doi:10.1016/j.ejvs.2006.11.022,

7. Thejasvi T., Caitlin E. K., Armstrong E. Peripheral artery diseases in patients with diabetes: Epidemiology, mechanism and outcomes. World Journal of Diabetes. 2015. Vol. 6, № 7. P. 961-969. DOI: doi: 10.4239/ wjd.v6.i7.961. URL: https://pubmed.ncbi.nlm.nih. gov/26185603/

8. Chin Y. H., Catherine M. S. Medial Arterial Calcification - An Overlooked Player in Peripheral Arterial Disease Arterioscler Thromb. Vasularc Biology. 2016. Vol. 36, № 8. P. 1475-1482. Jun 16. URL: https:// pubmed.ncbi.nlm.nih.gov/27312224/ DOI: doi: 10.1161/ATVBAHA.116.306717.

9. Faglia E. et al. Farly and five-year amputation and survival rate of diabetic patients with critical limb ischemia: data of a cohort study of 564 patients. European Journal of Vasular and Endovascular Surgery. 2006. Vol. 32, Supl. 5. P. 484-490. URL: https:// pubmed.ncbi.nlm.nih.gov/16730466/. DOI: doi: 10.1016/j.ejvs.2006.03.006

10. Shaper N. et al. IWGDF Editorial Board Practical Guidelines on the prevention and management of diabetic foot disease (IWGDF 2019 update). Diabetes/ Metabolism Reearch ands Reviews. 2020. Vol. 36 Suppl 1. https://pubmed.ncbi.nlm.nih.gov/32176447/ doi: 10.1002/dmrr.3266.

11.Snow D. E. et al. The presence of biofilm structures in atherosclerotic plaques of arteries from legs amputated as a complication of diabetic foot ulcers. Journal of Wound Care. 2016. № 25 (2). P. 16-22. URL: https://
pubmed.ncbi.nlm.nih.gov/?term=Snow + DE\&cauthor $\mathrm{id}=26878370$. DOI: doi: 10.12968/jowc.2016.25.Sup2. S16.

12.GVG Writing Group for the Joint Guidelines of the Society for Vascular Surgery (SVS), European Society for Vascular Surgery (ESVS) and World Federation of Vascular Societies (WFVS). Global Vascular Guidelines on the Management of Chronic LimbThreating Ichemia / Conte M. S., et. al. European Journal of Vasular and Endovascular Surgery. 2019. № 58(1S). P. 1-109. URL: https://www.ncbi.nlm.nih. gov/pubmed $/$ ?term $=$ Conte $\% 20 \mathrm{MS} \% 5 \mathrm{BAuthor} \% 5 \mathrm{D}$ $\&$ cauthor $=$ true $\&$ cauthor_uid $=31182334$. DOI: doi: 10.1016/j.ejvs.2019.05.006

13.Tefera G., Hoch J., Turnipseed W. D. Limb-salvage angioplasty in vascular surgery practice. Journal of Vascularc Surgery. 2005. № 41(6). P. 988-993. URL: https://pubmed.ncbi.nlm.nih.gov/15944598/. DOI: doi:10.1016/j.jvs.2005.03.018.

14.TASC II Working Group. Inter-Society Consensus for the Management of Peripheral Arterial Disease (TASC II) / Norgren L., Hiatt W. R., et. al. Journal of Vascular Surgery. 2007. № 45, P. 5-67. URL: https://www.ncbi. nlm.nih.gov/pubmed/?term =Norgren\%20L\%5BAuth or\%5D\&cauthor=true\&cauthor_uid $=17223489$. DOI: doi: $10.1016 /$ j.jvs.2006.12.037.

15. Taylor G. I., AO, MD. The angiosomes of the body and their supply to perforator flaps. Department of Plastic Surgery, Royal Melbourne Hospital, 7th Floor. Clinics in Plastic Surgery. 2003. № 30. P. 331-342. URL: https://pubmed.ncbi.nlm.nih.gov/12916590/. DOI: doi: 10.1016/s0094-1298(03)00034-8.

16.Jongsma H., et al. Angiosome-directed revascularization in patients with critical limb ischemia Journal of Vascular Surgery. 2017. № 65(4), P. 1208-1219. URL: https:// www.ncbi.nlm.nih.gov/pubmed/?term=Jongsma\%20 H\% 5 BAuthor\% 5D\&cauthor=true\&cauthor uid=28342514. DOI: doi: 10.1016/j.jvs.2016.10.100.

17.Spillerová K. et al. Angiosome Targeted PTA is More Important in Endovascular Revascularisation than in Surgical Revascularisation: Analysis of 545 Patients with Ischaemic Tissue Lesion. European Journal of Vasular and Endovascular Surgery. 2017. № 53. P. 567-575. URL: https://pubmed.ncbi.nlm.nih.gov/28215512/. DOI: doi: 10.1016/j.ejvs.2017.01.008.

18. Treatment of peripheral arterial disease in diabetes: A consensus of the Italian Societies of Diabetes (SID, AMD). / Aiello A., et. al. Radiology (SIRM) and Vascular Endovascular Surgery (SICVE). 2014. № 24(4). P. 355-69. URL: https://pubmed.ncbi.nlm. nih.gov/?term=Aiello+A\&cauthor_id=24486336. DOI: doi: 10.1016/j.numecd.2013.12.007.

19. Manzi M. et al.. Clinical results of below-the knee intervention using pedal-plantar loop technique for the revascularization of foot arteries. Journal of Cardiovascular Surgery (Torino). 2009. № 50(3). 
P. 331-337. URL: https://pubmed.ncbi.nlm.nih. gov/?term=Manzi+M\&cauthor_id=19543193

20. Faglia E.et al. Peripheral Angioplasty as the Firstchoice Revascularization Procedure in Diabetic Patients with Critical Limb Ischemia: Prospective Study of 993 Consecutive Patients Hospitalized and Followed Between 1999 and 2003. European Journal of Vasular and Endovascular Surgery. 2005. № 29(6).
P. 620-627 URL: https://pubmed.ncbi.nlm.nih. gov/?term $=$ Faglia + E\&cauthor_id $=15878541$. DOI: doi: 10.1016/j.ejvs.2005.02.035.

21. Kanda Y. Investigation of the freely available easyto-use software 'EZR' for medical statistics. Bone Marrow Transplant. 2013. № 48. P. 452-458. URL: https://pubmed.ncbi.nlm.nih.gov/23208313/. DOI: doi: 10.1038/bmt.2012.244

\section{REFERENCES}

1. Hirsch, A. T., Hiatt, W. R. (2001). PARTNERS: PAD Awareness, Risk and Treatment: New Resources for Survival. Vascular Medicine, 63 Suppl, 9-12. Available from: https://pubmed.ncbi.nlm.nih.gov/11789964/. doi: 10.1177/1358836X0100600i103

2. Selvin, E., Erlinger, T. P. (2004). Prevalence of and risk factors for peripheral arterial disease in the United States: results from the National Health and Nutrition Examination Survey. Circulation. Aug 10. 110(6). 738-43. Epub 2004 Jul 19. Available from: https:// pubmed.ncbi.nlm.nih.gov/15262830/. doi: 10.1161/01. CIR.0000137913.26087.F0.

3. Ahmad, N., Thomas, G. N., Paramjit, G., Torella, F. (2016). The prevalence of major lower limb amputation in the diabetic and non-diabetic population of England 2003-2013. Diabetes \& Vascular Disease Researc., Vol. 13 (5), 348-353. Available from: https://pubmed.ncbi.nlm.nih.gov/27334482/. doi: $10.1177 / 1479164116651390$

4. Bradbury, A. W., Adam, D., Bell, J., Forbes, F., Gerry, F., Fowkes, R., Gillespie, I. ... Ruckley, C.V. (2010). BASIL Trial Participants: Bypass versus Angioplasty in Severe Ischaemia of the Leg (BASIL) trial: A survival prediction model to facilitate clinical decision making. Journal of Vasularc Surgery, 51, 52-68. Available from: https://pubmed.ncbi.nlm.nih.gov/15262830/. doi: 10.1016/j.jvs.2010.01.077

5. Sjödin, L., Enocson, A., Rotzius, P. (2018). Increased mortality among patients with diabetes following firstever transfemoral amputation. Diabetes Research and Clinical Practice, 143, 225-231. Available from: https:// pubmed.ncbi.nlm.nih.gov/30009936/. doi: 10.1016/j

6. Graziani, L., Silvestro, A., Bertone, V., Manara, E., Andreini, R.,. Sigala, A $\backslash$.... De Giglio, R. (2007). Vascular Involvement in Diabetic Subjects with Ischemic Foot Ulcer: A New Morphologic Categorization of Disease Severity. European Journal of Vasular and Endovascular Surgery, 33, 453-460. Available from: http://www.sciencedirect.com. doi:10.1016/j. ejvs.2006.11.022,

7. Thejasvi, T, Caitlin, E K., Ehrin, J. A. (2015, Jul 10). Peripheral artery diseases in patients with diabetes: Epidemiology, mechanism and outcomes. World Journal of Diabetes., 6(7), 961-9. Available from: https:// pubmed.ncbi.nlm.nih.gov/26185603/. doi: 10.4239/ wjd.v6.i7.961

8. Chin, Y. H., Catherine, M. (2016). Shanahan Medial Arterial Calcification - An Overlooked Player in Peripheral Arterial Disease Arterioscler Thromb. Vasularc Biology, 36(8), 1475-82. Available from: https://pubmed.ncbi.nlm.nih.gov/27312224/. doi: 10.1161/ATVBAHA.116.306717

9. Faglia, E., Clerici, G., Clerissi, J., Gabrielli, L., Losa, S., Mantero, M., Caminiti, M \.... Morabito, A. (2006). Early and five-year amputation and survival rate of diabetic patients with critical limb ischemia: data of a cohort study of 564 patients. European Journal of Vasular and Endovascular Surgery, 32(5), 48490. Available from: https://pubmed.ncbi.nlm.nih. gov/16730466/. doi: 10.1016/j.ejvs.2006.03.006

10. Nicolaas, C. S., van Netten, J.,Apelqvis, J., Sicco, A. B., Hinchliffe, R., Lipsky, B., (2020). IWGDF Editorial Board Practical Guidelines on the prevention and management of diabetic foot disease (IWGDF 2019 update). Diabetes/Metabolism Reearch ands Reviews, 36, 1, e3266. Available from: https://pubmed.ncbi.nlm. nih.gov/32176447/. doi: 10.1002/dmrr.3266

11.Snow, D. E., Everett,J., Mayer,G., Cox, S B, Miller,B.., Rumbaugh, K.... Wolcott, R D. (2016).The presence of biofilm structures in atherosclerotic plaques of arteries from legs amputated as a complication of diabetic foot ulcers. Journal of Wound Care, 25(2), S16-22. Available from: https://pubmed.ncbi.nlm.nih. gov $/$ ?term $=$ Snow + DE\&cauthor_id $=26878370$. doi: 10.12968/jowc.2016.25.Sup2.S16.

12. Conte, M.S., Bradbury, A.W., Kolh, P, White, J.V., Dick, F., Fitridge, R ... Shenming, W. (2019). GVG Writing Group for the Joint Guidelines of the Society for Vascular Surgery (SVS), European Society for Vascular Surgery (ESVS) and World Federation of Vascular Societies (WFVS). Global Vascular Guidelines on the Management of Chronic Limb-Threating Ichemia, 58, 1-109. Available from: https://www.ncbi.nlm.nih.gov/ pubmed/?term $=$ Conte\%20MS\%5BAuthor\%5D\&ca uthor=true $\&$ cauthor_uid $=31182334$. doi: $10.1016 / j$. ejvs.2019.05.006.

13.Tefera, G., Hoch, J., Turnipseed, W.D. (2005). Limb-salvage angioplasty in vascular surgery practice. 
Journal of Vascularc Surgery, 41(6), 988-993. Available from: https://pubmed.ncbi.nlm.nih.gov/15944598/ doi:10.1016/j.jvs.2005.03.018

14. Norgren, L., Hiatt, W. R., Dormandy, J. A., Nehler, M. R., Harris K. A., Fowkes F. G. (2007). TASC II Working Group. Inter-Society Consensus for the Management of Peripheral Arterial Disease (TASC II). Journal of Vascular Surgery, 45 (1), 5-67. Available from: https:// www.ncbi.nlm.nih.gov/pubmed/?term $=$ Norgren $\% 20$ L\% 5BAuthor\% 5D\&cauthor=true\&cauthor uid=17223489 doi: 10.1016/j.jvs.2006.12.037

15. Taylor, G. I. (2003). The angiosomes of the body and their supply to perforator flaps. Department of Plastic Surgery, Royal Melbourne Hospital, 7th Floor, 766 Elizabeth Street, Melbourne 3000, Australia. Clinics in Plastic Surgery, 30, 331-342. Available from: https:// pubmed.ncbi.nlm.nih.gov/12916590/. doi: 10.1016/ s0094-1298(03)00034-8

16.Jongsma, H., Bekken, J. A., Akkersdijk, G. P., Hoeks, S. E., Verhagen H. J., Fioole, B. (2017). Angiosomedirected revascularization in patients with critical limb ischemia, 65(4), 1208-1219. Available from: https:// www.ncbi.nlm.nih.gov/pubmed/?term=Jongsma $\% 20$ H\% 5 BAuthor\% 5D\&cauthor=true\&cauthor_ uid=28342514. doi: 10.1016/j.jvs.2016.10.100.

17.Spillerová, K., Settembre, N., Biancari,.F, Albäck, A., Venermo, M. (2017). Angiosome Targeted PTA is More Important in Endovascular Revascularisation than in Surgical Revascularisation: Analysis of 545 Patients with Ischaemic Tissue Lesion. European Journal of Vasular and Endovascular Surgery, 53, 567-575. Available from: https://pubmed.ncbi.nlm.nih.gov/28215512/ doi: 10.1016/j.ejvs.2017.01.008

18. Aiello, A., Anichini, R., Brocco,E., Caravaggi,C., Chiavetta, A. (2014, Dec). Treatment of peripheral arterial disease in diabetes: A consensus of the Italian Societies of Diabetes (SID, AMD), Radiology (SIRM) and Vascular Endovascular Surgery (SICVE). Nutrition, Metabolism \& Cardiovascular Diseases, 24(4), 355-369. Available from: https://pubmed. ncbi.nlm.nih.gov/?term=Aiello+A\&cauthor_id=24486336. doi: 10.1016/j.numecd.2013.12.007.

19. Manzi, M., Fusaro, M., Ceccacci., T, Erente, G., Paola D., Brocco E. (2009). Clinical results of below-the knee intervention using pedal-plantar loop technique for the revascularization of foot arteries. Journal of Cardiovascular Surgery (Torino), 50 (3), 331337. Available from: https://pubmed.ncbi.nlm.nih. gov/?term=Manzi+M\&cauthor_id=19543193.

20.Faglia, E.et al. (2005). Peripheral Angioplasty as the First-choice Revascularization Procedure in Diabetic Patients with Critical Limb Ischemia: Prospective Study of 993 Consecutive Patients Hospitalized and Followed Between 1999 and 2003. European Journal of Vasular and Endovascular Surgery, 29 (6), 620627. Available from: https://pubmed.ncbi.nlm.nih. gov $/$ ?term $=$ Faglia + E\&cauthor_id $=15878541$ doi: 10.1016/j.ejvs.2005.02.035.

21. Kanda, Y. (2013). Investigation of the freely available easy-to-use software 'EZR' for medical statistics. Bone Marrow Transplant, 48, 452-458. Available from: https://pubmed.ncbi.nlm.nih.gov/23208313/ doi: 10.1038/bmt.2012.244

\section{Резюме}

\section{ОСОБЛИВОСТІ РЕВАСКУЛЯРИЗАЦІЇ НИЖНІХ КІНЦІВОК У ХВОРИХ НА ДІАБЕТИЧНУ СТУПНЮ Д. Шаповалов, Ю. Гупало, В. Шапринський, А. Шамрай-Сас, А. Куцин, В. Гур'янов}

Державна наукова установа «Науково-практичний центр профілактичної та клінічної медицини» Державного управління справами, Київ, Україна

Мета: Визначити особливості уражень периферичних артерій у пацієнтів з синдромом діабетичної стопи, які слід враховувати при виборі метода реваскуляризації.

Вступ: Захворювання периферичних артерій у пацієнтів з синдромом діабетичної стопи (ЗПА/САС) суттєво відрізняються за патогенезом, проявами та перебігом від суто атеросклеротичних уражень. Ці відмінності спричинили створення окремих класифікацій для визначення ступеню важкості захворювання. Однак підходи до реваскуляризації в обох випадках зазвичай залишаються однаковими. Вибір метода реваскуляризації з урахуванням особливостей ЗПА/САС можуть покращити ефективність втручання. Матеріали та методи: Ми проаналізували результати 98 реваскуляризацій 77 нижніх кінцівок у 74 пацієнтів за період з 2014 по 2019. Ангіопластика виконана в 72,3\%, відкрите втручання - в 21,4\%, гібридне-в 6,1\%. Результати. Показник виживання без ампутації протягом 1 року склав 84,6\%, загоєння трофічних порушень протягом 1 року - 70,5\%.

Висновки. Ще на етапі діагностики паціенти з ЗПА/САС та ЗПА мають бути відокремлені для створення диференційованого лікування та окремого вибору методики реваскуляризації. Окремий підхід до пацієнтів з ЗПА/САС може покращити результати реваскуляризації.

Ключові слова: захворювання периферичних артерій, синдром діабетичної стопи, ангіопластика, ангіосомно-спрямована реваскуляризація 


\section{Резюме}

\section{ОСОБЕННОСТИ РЕВАСКУЛЯРИЗАЦИИ НИЖНИХ КОНЕЧНОСТЕЙ У БОЛЬНЫХ С ДИАБЕТИЧЕСКОЙ СТОПОЙ Д. Шаповалов, Ю. Гупало, В. Шапринский, А. Шамрай-Сас, А. Куцин, В. Гурьянов}

Государственное научное учреждение «Научно-практический центр профилактической и клинической медицины» Государственного управления делами, Киев, Украина

Цель: определить особенности заболеваний периферических артерий у пациентов с синдромом диабетической стопы, которые следует учитывать при выборе метода реваскуляризации.

Вступление: Заболевания периферических артерий у пациентов с синдромом диабетической стопы (ЗПА/САС) существенно отличаются по патогенезу, проявлениям и течению от чисто атеросклеротических поражений. Эти особенности привели к созданию отдельных классификаций для определения степени тяжести заболевания. Подходы подходи к реваскуляризации в обоих случаях обычно остаются одинаковыми. зазвичай залишаються одинаковыми. Выбор методики реваскуляризации с учетом особенностей ЗПА/САС могут улучшить эффективность вмешательства.

Материалы и методы: Мы проанализировали результаты 98 реваскуляризаций 77 нижних конечностей у 74 пациентов за период с 2014 по 2019 гг. Ангиопластика выполнена в 72,3\% случаев, открытое вмешательство - в 21,4\%, гибридное - в 6,1\%.

Результаты. Показатель выживания без ампутации на протяжении 1 года составил 84,6\%, заживления трофических нарушений в течение 1 года - 70,5\%.

Выводы. Еще на диагностическом этапе пациенты с ЗПА/САС и ЗПА должны быть разделены для создания дифференцированного лечения отдельного выбора методики реваскуляризации. Отдельный подход к пациентам с ЗПА/САС может улучшить результаты реваскуляризации.

Ключевые слова: заболевания периферических артерий, синдром диабетической стопы, ангиопластика, ангиосомно-направленная реваскуляризация.

Інформація про авторів знаходиться на сайті http://www.cp-medical.com.

Дата надходження до редакції - 11.08.2020 